\title{
First-party and third-party food delivery apps, which is better in Indonesia?
}

\author{
Kartika Aprilia Benhardy ${ }^{1)}$, Matthew Ronadi ${ }^{2)}$ \\ ${ }^{1,2)}$ Management Department, Bina Nusantara University, Jakarta, Indonesia \\ Corresponding author: kbenhardy@binus.edu
}

\begin{abstract}
Indonesia is a nation with considerable GDP growth because of high household consumptions. One of the contributors to household consumption is eating out, which drives the growth of online ordered food in Indonesia. Ordering food online can be done through a website and via application of that restaurant (firstparty) or through third-party food delivery apps. This research wants to investigate further what factors are considered by the consumer when choosing an online food delivery app and also deciding if consumers prefer to use first-party or third-party food delivery apps. The field of this research is limited to Pizza Delivery Apps, and Analytic Hierarchy Process (AHP) is used to determine which factors are the most considered by consumers when choosing an application. The respondents of this research are just five people who have used pizza delivery apps in the past few months, and a geometric mean calculated to analyze the results. The results show that Trustworthiness and E-Service Quality are the most considered factors by consumers when choosing a food delivery app. Consumers highly consider first party food delivery apps which are PHD and Domino's Pizza become the choice of consumers because of higher Trustworthiness factors. Third-party food delivery apps, which are Go-Jek and Grab, were rated by consumers to have a lower trust factor compared to first-party apps. This research shows food delivery apps by a restaurant (firstparty) has it is own advantage compared to third-party food delivery apps.
\end{abstract}

Keywords: Food Delivery App, Trustworthiness, E-Service Quality, Analytic Hierarchy Process

\section{Introduction}

Indonesia is a country that has experienced significant economic growth because it has supported by substantial household consumption. 56\% of Indonesia's GDP currently consists of Household consumptions (Indonesia Investments, 2018). Indonesians tend to have high household consumption because of their culture; Indonesians tend to have a habit of eating out than cooking by themselves. This fact supported by a survey done by Qraved.com (2013). That research also says that Indonesians tend to eat outside as a social activity in their daily lives where they socialize and gather with friends, family, or co-workers (Global Business Guide Indonesia, 2017). A report also stated that Indonesians tend to be lazy and prefer to use Grab or Gojek to deliver food (CNN Indonesia, 2019). These factors have made the food and beverage industry in Indonesia achieved a growth of 8.67\%, which is higher than the Indonesian GDP during Q2 2018 at the time.

Many smaller Indonesian restaurants do not have an option to deliver the food themselves, and this is were many third party food deliveries fill the gap. Gojek and Grab fill have spurred growth in the food and beverage industry. It is the reason why d online food delivery in Indonesia experienced significant growth, where it has reached 1.684 Billion USD or experienced growth of $23.8 \%$ than last year (Stastitsa, 2018). Currently, $91.7 \%$ of Online Food Delivery considered as the restaurant to consumer delivery, which shows that Indonesians like to order food online. (Restaurant to Consumer Delivery is food ordered online, which is done through the website/application of the restaurant or third party and is delivered to the consumer directly by the restaurant or a third party).

The transaction value of ordering food online has to increase significantly because of applications such as Go-Jek that provide food delivery services such as Go-Food, where Go-Food also has become one of the biggers food delivery apps in the world outside of China (Markeeters.com, 2018). Based on third party research in 2019, Go-Food has become the most service compared to other similar services. The founder and CEO of Gojek even stated that his service had become the third-largest in the world (Hiddayah, 2019). As of now, Go-Food has more than 125 thousand merchants, and $80 \%$ of those merchants are small or medium culinary businesses.

Grab also has a similar food delivery service, which is named Grabfood, to compete with Go-Jek. Grab food was launched a year after Go-Food, but Grabfood has also managed to overgrow as well, which is shown by the number of orders that have increased six times and the number of merchants that have grown eight times since it is the launch (Detik.com, 2018). Currently, Grab food is trying to catch up with GoFood because GoFood more frequently used by consumers (CNN Indonesia, 2019). Those two applications are now competing fiercely to become the largest food delivery service and online ojek in Indonesia.

Go-Food and Grabfood have both become the preferred online food ordering application by consumers. Large restaurants such as KFC, Pizzahut, Domino's Pizza, McDonald's, and a few other large restaurants have their application to order food online individually from their restaurants. Food ordering application from the restaurants themselves is not as popular Go-Food and GrabFood in Indonesia. Some large restaurants 
themselves have shifted to using third party food ordering applications instead of managing their applications. One unique case showed that PT. Fast Food Indonesia Tbk or KFC for food delivery services fell in 2018, but they also experienced growth in their sales because of the help of third party services such as GoFood and GrabFood (Ayuningtyas, 2019). However, they are still a few restaurants that prefer to use their application to manage orders online accurately for their restaurant than using third-party applications.

This research wants to investigate further if online food ordering application from the restaurant (firstparty) can compete with online food ordering application from a third party such as GrabFood and Go Food. This research itself will focus on one specific food type, which is Pizza. The food type in this research is predetermined to give homogeneity for the obtained data and make the comparisons process easier. The pizza was chosen because the Pizza food delivery App such as PHD and Domino's Pizza, has relatively good ratings on the GooglePlay Store than the other food ordering applications from large restaurants. The specified food type in this research also makes it easier for the researcher to compare online food ordering applications that used when comparing them to third-party ordering food applications such as Go-Food and GrabFood.

Previous research that has done about online food ordering applications by various researchers has a perspective of the adoption of the application with TAM and the UTAUT2 model used in their research. The purpose of this research is to instead compare online food ordering application for pizza between first party and third party application and not the adoption itself. The following dimensions used to perform the comparison, and those dimensions are service quality, price saving orientation, trust, and customer satisfaction, which are taken from various literature and discussed in the next section.

\section{Literature Review}

\section{Service Quality \& E-Service Quality}

Service is something that needs the utmost attention in E-Commerce, which includes Online Food Delivery. The company must pay attention to both Service Quality and E-Service Quality that is related to Online Food Delivery. Service Quality is the comparison of consumers' perception of a specific service with their consumer expectation when using that service (Tamiselvi, 2016). Service Quality itself has 3 components, which are people, process, and physical evidence. In this case of Online Food Delivery through Mobile Apps, therefore the people component in Service Quality has an essential role in food delivery and customer service mainly to deal with problems that may arise in the delivery process. Physical evidence in this research can define as physical evidence that reassures the consumer about the service given by the company. In this case, it could be the application itself or the uniform/attribute in the food delivery process. Lastly, process, in this research process, can be inferred as the system that used to receive the order, management, and delivery. Process in online Food Delivery can state as the application itself that used to make the order. Service quality in this research will be divided into two attributes, which are delivery and customer satisfaction. Delivery, in this case, has the scope of everything related to food delivery and the time required to deliver food to customers. The other attribute is customer service, which is the support given to the customer to help them with the order or how the company deals with problems if one arises.

The process and system used to order food that can be done through an application show that there is an aspect of E-Service Quality. Parasuraman et al. (2005) suggested that "Service quality on the internet is the area to which the website facilitates shopping, buying, and shipping of products and services that are efficient and effective". E-Service Quality can be divided into several elements, which are process, outcome, and recovery (Collier \& Bienstock, 2003). The process dimension has several aspects as well, which are Privacy, Design, Information Accuracy, Ease of Use, and Functionality. (Collier \& Bienstock, 2003).

This research focuses on food ordering applications and not the restaurant's website that can also use to take orders. Where (Kapoor \& Vij, 2018) previously made a model that has corresponding dimensions for a mobile application, these dimensions are namely Information Design, Visual Design, Navigational Design dan Collaboration Design. Visual Design can be interpreted as the aesthetic design of the application, which can include how the images, colors, and frames are composed of the application. Visual Design can influence someone to use an application. Information Design can be interpreted as how the information presented in the application for the user/consumers, the information given in the application must be made clear and accurate for the consumers so they can make informed decisions. (Kapoor \& Vij, 2018) researched show that "an efficient and helpful mobile app information design expected to have a positive impact on conversion." (Conversion in that research is the equivalent of sales). Lastly, Navigational Design refers to the design of the mobile app and how it is contents organized. An application with a good navigation design is necessary, so the user/consumer find the menu they want to use quickly.

The research done by (Kapoor \& Vij, 2018) discusses Online Food-Delivery Aggregators (OFA's) in India, where one dimension is Collaboration Design is not used in this research because that dimensions have a different scope and is not too appropriate for this research.

\section{Trust}

Trust plays an essential factor and must be considered when shopping online, which applies to online food delivery as well. Indeed has become a basis for forming feeling security for consumers when they shop 
online (Alagoz \& Hekimoglu, 2012). A lack of trust can hinder the consumer from shopping online or cause them to avoid performing transactions online altogether. Trust, therefore, plays an essential role for both the seller and the buyer when performing an online transaction (Isa et al., 2016). The research from (Cho, Bonn, $\& \mathrm{Li}, 2018$ ) yielded similar results where trust is an essential factor for the perceived value of Food Delivery Services. Building trust in Online Food Delivery forces companies to pay attention to information quality, website design, security/privacy, and payment system (Kedah et al., 2015). Trust plays an essential role in building customer loyalty as well, (Cho, Bonn, \& Li, 2018) suggested that "user-trustworthiness can play an important role in decision making for online shopping, which in terms of greater loyalty for using mobile apps."

Building trust in applications is not a straightforward process, so the application must be able to build a sense of security to the consumers when using the application. Because trust is a form of relationship, the company that makes the application must be able to maintain reliable services for consumers, for this application, it means the reliability of the application. In the case of Online Food Delivery apps, the application has to be able to integrate these attributes mentioned previously to build trust with the consumers effectively.

\section{Price Saving Orientation}

Price Saving Orientation is an orientation of a person to save money when purchasing a specific product. Price Saving Orientation has a positive relationship with online purchases for Online Travel Shopping (Jensen, 2012). Other research also in the field online airline tickets yielded similar results where the more significant the price saving, then the higher the possibility someone obtains a product with the price they think is worth it and the more significant benefit they feel (Rodriguez \& Trujillo, 2013). Research in the Online Food Delivery Industry has been done by (Yeo, Goh, \& Rezaei, 2017), their research used Price Saving Orientation with a result where consumer tends to pay attention to prices and discounts when they are shopping online which include Online Food Delivery.

\section{Customer Satisfaction}

Satisfaction, according to (Kotler \& Keller, 2012) is “ a person's feelings of pleasure or disappointment that result from comparing a product's perceived performance (or outcome) to expectations.” That definition shows that Online Food Delivery Services has to be able to manage expectations and service performance to the consumer so they can feel satisfied with the services offered by the company. Several factors influence customer satisfcation in Online Shopping. An empirical study by (Kedah et al., 2015) shows that Online Food Delivery in influenced by Service Quality and Website Design. Website Design in this research can be equalized with E-Service Quality, as discussed before in the Service Quality section. Liu et al. (2008) have also done similar research about Online shopping. The research shows that Website Design, Information design, delivery, and Customer Service have a significant impact on Customer Satisfaction. Customer satisfaction in Online Food Delivery can make consumers more loyal to a specific Online Food Delivery Service (Kedah et al., 2015). Consumers that are satisfied with their online food service can make a repeat purchase and even promote that Online Food Delivery to other customers. Likewise, limited pleasant experience for customers can make them not recommend services to others (Suhartanto et al., 2018). Customer satisfaction is not measured explicitly in this study but plays an essential role because respondents must choose which is an attribute and based on satisfaction for each attribute.

\section{Research Method}

This research is descriptive, the purpose of this research is to know the most considered factors when choosing Online Food Delivery App. These factors in this research are divided into four categories, which are Service Quality, E-Service Quality, Trustworthiness, and Price Saving Orientation. The research method using the Analytic Hierarchy Process (AHP). The data was processed using Super Decision to determine which Online Food Delivery App is the best. Analytic Hierarchy Process itself is a structured technique for dealing with complex decisions (Ameri, 2013). AHP can provide a comprehensive solution to solve quantitative problems or achieving solutions to solve a problem. AHP analysis done by comparing pairs of objects or attributes to see which attribute is more important between the two. An object can have several sub-attributes that can be taken into account in this research. In this research, each factor will have several attributes shown in Table 1. It is done, so each aspect of an attribute analyzed and gave complete results.

The online food delivery that research is only for applications that can order pizza online. This research compares first-party and third-party Online Food Delivery Apps. The research itself uses five respondents who have used those four applications in the last six months. The respondent's answer gathered, and the analysis was done using a geometric mean then calculated using AHP. Geometric mean is used instead of this research to reduce the effect of outliers and provide a more accurate score that compounds for each attribute/factor in this research. 
Variable Operationalization

Table 1. Variable Operationalization

\begin{tabular}{ll}
\hline \multicolumn{1}{c}{ Factor } & \multicolumn{1}{c}{ Sub Attribute } \\
\hline \multirow{2}{*}{ Service Quality } & Delivery \\
\cline { 2 - 2 } E-Service Quality & Customer Service \\
\hline \multirow{2}{*}{ Trustworthiness } & Information Design \\
\cline { 2 - 2 } & Visual Design \\
\hline \multirow{2}{*}{ Price Savingational Design } \\
\cline { 2 - 2 } & Trust \\
\cline { 2 - 2 } & Security \\
\hline
\end{tabular}

Result and Discusssion

Table 2. Online Food Delivery App Attribute Analysis

\begin{tabular}{lc}
\hline \multicolumn{1}{c}{ Factor } & Geometric Mean \\
\hline E-Service Quality & 0.297672 \\
\hline Price Saving Orientation & 0.199815 \\
\hline Service Quality & 0.096870 \\
\hline Trustworthiness & 0.405644 \\
\hline
\end{tabular}

Table 3. Best Online Food Delivery App Evaluation

\begin{tabular}{lc}
\multicolumn{1}{c}{ Online Food Delivery App } & Geometric Mean \\
\hline Domino's Pizza & 0.260473 \\
\hline Gojek & 0.232801 \\
\hline Grab & 0.151250 \\
\hline PHD & 0.355476 \\
\hline
\end{tabular}

\section{Online Food Delivery Attribute Analysis Results}

Based on the results in table 2, the factors considered by consumers when using an Online Food Delivery App in order are Trustworthiness, E-Service Quality, Price Saving Orientation, and Service Quality. Trust (Trustworthiness) becomes the most considered factor when choosing an Online Food Delivery App. The result is in line with the research of Kedah, Ismail, Haque, \& Ahmed (2015) which shows that website trust has a significant relationship with customer satisfaction. It shows that consumers put a high priority on trust when choosing the application.

The second most considered factor is E-Service Quality. E-Service Quality in this research is the process and system used to order food or to perform online orders. These factors, which are Trustworthiness and EService Quality, comprise 70\% of the factors considered by consumers when using an Online Food Delivery App, and the rest factors which are $30 \%$ governed by the Price Saving Orientation Factors \& Service Quality Factors

\section{Online Food Delivery App Evaluation}

Table 4. Reliability Attribute

\begin{tabular}{|c|c|}
\hline Application & Geometric \\
\hline Domino's Pizza & 0.275920 \\
\hline Gojek & 0.151701 \\
\hline Grab & 0.075589 \\
\hline PHD & 0.496758 \\
\hline \multicolumn{2}{|c|}{ Table 5. Reliability Attribute } \\
\hline Application & Geometric \\
\hline Domino's Pizza & 0.323609 \\
\hline Gojek & 0.149772 \\
\hline Grab & 0.090376 \\
\hline PHD & 0.436243 \\
\hline \multicolumn{2}{|c|}{ Table 6. Trust Attribute } \\
\hline Application & Geometric \\
\hline Domino's Pizza & 0.297672 \\
\hline Gojek & 0.199815 \\
\hline Grab & 0.096870 \\
\hline PHD & 0.405644 \\
\hline
\end{tabular}


Based on Table 3, the best Online Food Delivery App for Pizza Indonesia, according to the consumers are (in order) Pizza Hut Delivery (PHD), Domino's Pizza, Gojek dan Grab. Food ordering applications, especially the first party or conducted by the restaurant themselves, which are PHD and Domino's Pizza, tend to have a higher score than third party food ordering Applications like Go-Food and GrabFood. Consumers have a higher level of trust for first-party applications compared to third party applications. In all cases, trust plays the most crucial role when ordering food online, which makes PHD and Domino's Pizza, the most favored application.

Table 7. Visual Design Attribute

\begin{tabular}{lc}
\hline \multicolumn{1}{c}{ Application } & Geometric Mean \\
\hline Domino's Pizza & 0.243587 \\
\hline Gojek & 0.39065 \\
\hline Grab & 0.157262 \\
\hline PHD & 0.2085 \\
\hline
\end{tabular}

Table 8. Information Design Attribute

\begin{tabular}{lc}
\hline \multicolumn{1}{c}{ Application } & Geometric Mean \\
\hline Domino's Pizza & 0.248694 \\
\hline Gojek & 0.259027 \\
\hline Grab & 0.119038 \\
\hline PHD & 0.376257 \\
\hline
\end{tabular}

Table 9. Navigational Design Attribute

\begin{tabular}{lc}
\hline \multicolumn{1}{c}{ Application } & Geometric Mean \\
\hline Domino's Pizza & 0.136979 \\
\hline Gojek & 0.306573 \\
\hline Grab & 0.180191 \\
\hline PHD & 0.376257 \\
\hline
\end{tabular}

Overall PHD and Domino's Pizza Applications have higher scores for the two most considered attributes. However, there are two attributes in both applications that have lower scores when compared to GrabFood and Go-Food. These two attributes are Visual Design (Table 7), which is a component of E-Service Quality a Sales Promotion (Table 10), which is a component of Price Saving Orientation.

Table 10. Sales Promotion Attribute

\begin{tabular}{lc}
\hline \multicolumn{1}{c}{ Application } & Geometric Mean \\
\hline Domino's Pizza & 0.220237 \\
\hline Gojek & 0.25481 \\
\hline Grab & 0.414975 \\
\hline PHD & 0.109978 \\
\hline
\end{tabular}

Table 11. Price Attribute

\begin{tabular}{lc}
\multicolumn{1}{c}{ Application } & Geometric Mean \\
\hline Domino's Pizza & 0.332469 \\
\hline Gojek & 0.202422 \\
\hline Grab & 0.22672 \\
\hline PHD & 0.238338 \\
\hline
\end{tabular}

Third-party food Delivery Apps such as Grab and Gojek frequently use promotions to encourage ordering food through their applications. Consumers tend to make use of these promos that are offered by the application. PHD \& Domino's Pizza also conducts promotions to the consumers to order via their application, but consumers tend to remember the promotions by Gojek and Grab. The promos offered by PHD a Domino's Pizza can be equally enjoyable as the promos offered by Gojek dan Grab. Therefore the communication by those PHD \& Domino's Pizza should be reconsidered to be more productive.

From an E-Service Quality, Gojek is an application with the most impressive visual design to be seen by the consumers. PHD and Domino's Pizza application have lower scores that Gojek in Visual Design, Domino's Pizza also have even worse scores than PHD for the Information Design and Navigational Design attribute. PHD itself has higher scores than GoJek for Information Design \& Navigational Design. Overall eservice quality-wise, PHD is the best application followed by Gojek and Domino's Pizza. 
Table 12. Customer Service Attribute

\begin{tabular}{lc}
\hline \multicolumn{1}{c}{ Application } & Geometric Mean \\
\hline Domino's Pizza & 0.244805 \\
\hline Gojek & 0.2401 \\
\hline Grab & 0.126234 \\
\hline PHD & 0.388862 \\
\hline
\end{tabular}

Table 13. Delivery Attribute

\begin{tabular}{lc}
\hline \multicolumn{1}{c}{ Application } & Geometric Mean \\
\hline Domino's Pizza & 0.189712 \\
\hline Gojek & 0.336998 \\
\hline Grab & 0.231549 \\
\hline PHD & 0.241741 \\
\hline
\end{tabular}

Service quality is the least contributing factor when choosing food application delivery, but some impressive results can show from the analysis. Based on table 12 and table 13, both customer service and delivery attributes have evenly distributed scores between applications. One interesting point is that Gojek seems to be perceived to have the best delivery compared to the other apps. From a customer service perspective, the best is PHD which shows that the company can deal with arising problems quickly in the delivery process.

\section{Conclusion}

The research shows that Food Delivery App from that restaurant (first-party) has a competitive advantage compared to third-party delivery apps. This advantage is in the form of high levels of trust towards first-party food delivery apps compared to third-party food delivery apps. Consumers consider trust as a critical factor in choosing a Food Delivery App; therefore, companies should focus on building consumer trust if they want their application to be successful.

E-Service Quality becomes the second most considered factor by consumers when choosing a Food delivery App. Its means a restaurant has to be able to make their application with excellent Information Design, Visual Design dan Navigational Design. One point that can be noted is that Visual Design for firstparty food delivery Applications such as Domino's Pizza and PHD can be improved because it currently has a lower score than third Party Application, which is Gojek. Companies, therefore, need to continuously improve the application to meet the needs of the consumer because it changes continuously as well.

Sales Promotion Attribute is also an aspect that needs to be paid attention to from first-party Food Delivery Apps. Even though it is not the most critical factor, third party Food Delivery Apps tend to have a higher score than First Party Food delivery Apps. There is potential for First Party Delivery Apps to increase this attribute to increase their competitiveness.

As stated earlier, this research only has scope for specific food types, which is Pizza. The results of this research are potentially not generalizable toward the entire Food Delivery App industry, and there are still other factors that need to be considered. One other important aspect consider is that Gojek and Grab can deliver various food types and not just only one when compared to first-party Food Delivery apps. They have a more limited scope of food types and potentially have lower awareness of third-party food delivery apps. Nonetheless, this research hopes to help restaurants with their own Food Delivery Apps make more informed and strategic decisions in the future.

\section{References}

Alagoz, S. M., \& Hekimoglu, H. (2012). A Study on TAM: Analysis of consumer attitudes in online food ordering system. Procedia - Social and Behavioral Sciences, (pp. 1138-1143).

Ameri, A. (2013). Application of the Analytic Hierarchy Process (AHP) for Prioritize of Concrete Pavement. Global Journal of HUMAN SOCIAL SCIENCE, 18-28.

Ayuningtyas, D. (2019, March 27). GoFood \& GrabFood Bikin Penjualan KFC Naik 13,89\%. Retrieved from www.cnbcindonesia.com: https://www.cnbcindonesia.com/market/20190327171002-17-63265/gofoodgrabfood-bikin-penjualan-kfc-naik-1389

Cho, M., Bonn, M. A., \& Li, J. (2018). Differences in perceptions about food delivery apps between singleperson and multi-person households. International Journal of Hospitality Management.

CNN Indonesia. (2019, 7 16). Grab Kuasai Pasar Ojol Indonesia, Grabfood Kalah dari Gofood. Retrieved from www.cnnindonesia.com: https://www.cnnindonesia.com/teknologi/20190715190631-185412344/grab-kuasai-pasar-ojol-indonesia-grabfood-kalah-dari-gofood

CNN Indonesia. (2019, 1 31). Kemalasan Masyarakat jadi Keuntungan GrabFood dan GoFood. Retrieved from www.cnnindonesia.com: https://www.cnnindonesia.com/teknologi/20190130201108-185365194/kemalasan-masyarakat-jadi-keuntungan-grabfood-dan-gofood 
Collier, J. E., \& Bienstock, C. C. (2003). A Conceptual Framework for Measuring Service Quality. Academy of Marketing Science, (pp. 158-162).

Detik.com. (2018, Des 12). Bagaimana Cara Grab Jadikan GrabFood Nomor 1 di Indonesia? Retrieved from www.inet.detik.com: https://inet.detik.com/business/d-4339697/bagaimana-cara-grab-jadikan-grabfoodnomor-1-di-indonesia

Global Business Guide Indonesia. (2017). Indonesian Restaurant \& Franchise Sector: Technology Key to Future Growth. Retrieved from ww.gbgindonesia.com: http://www.gbgindonesia.com/en/services/article/2017/indonesia_s_restaurant_and_food_franchise_secto r_technology_and_innovation_key_to_future_growth_11800.php

Hiddayah, A. (2019, April 16). Go-Food 4 Kali Lebih Besar Dari Grab Food, Nomor 3 Terbesar di Dunia. Retrieved from www.moneysmart.id/: https://www.moneysmart.id/go-food-jadi-layanan-pesan-antarmakanan-paling-populer/

Indonesia Investments. (2018, May 7). Produk Domestik Bruto Indonesia. Retrieved from www.indonesiainvestments.com: https://www.indonesia-investments.com/id/keuangan/angka-ekonomi-makro/produkdomestik-bruto-indonesia/item253

Isa, N., Rasli, A., Khan, F., \& Mdyusoff, R. (2015). Impact of Trust on Online Shopping: A Systematic Review of Literature. Journal of Advanced Review on Scientific Research, 1-8.

Jensen, J. M. (2012). Shopping Orientation and Online Travel Experience. International Journal of Toruism Research, 56-70.

Kapoor, A. P., \& Vij, M. (2018). Technology at the dinner table: Ordering food online through mobile apps. Journal of Retailing and Consumer Services, 342-351.

Kedah, Z., Ismail, Y., Haque, A., \& Ahmed, S. (2015). Key Success Factors of Online Food Ordering Services: An Empirical Study. Malaysian Management Review Vol 50 No.2, 19-36.

Kotler, P., \& Keller, K. L. (2012). Marketing Management. New Jersey: Pearson.

Lee, E.-Y., Lee, S.-B., \& Jeon, Y. J. (2017). Factors influencing the behavioral intention to use food delivery apps. Social Behavior and Personality 45(9), 1461-1474.

Liu, W., \& Florkowski, W. (n.d.). Online Meal delivery services: Perception of service quality and delivery speed among Chinese consumers.

Markeeters.com. (2018, January 10). GO-FOOD Jadi Layanan Pesan Antar Makanan Terbesar di Dunia. Retrieved from www.marketeers.com: http://marketeers.com/go-food-menjadi-layanan-pesan-antarmakanan-terbesar-di-dunia/

Rodriguez, T. E., \& Trujillo, E. C. (2013). Online drivers of consumer purchase of website airline tickets. Journal of Airport Transport Management, 58-64.

Statista.com. (n.d.). Online Food Delivery : Indonesia. Retrieved from www.statista.com: https://www.statista.com/outlook/374/120/online-food-delivery/indonesia

Suhartanto, D., Ali, M. H., Tan, K. H., Sjahroeddin, F., \& Kusdibyo, L. (2018). Loyalty toward online food delivery service: the role of e-service quality and food quality. Journal of Foodservice Business Research, $1-17$.

Tamiselvi, M. (2016). Service Quality - Customer Satisfaction. IOSR Journal of Business and Management , 29-31.

Yeo, V. C., Goh, S.-K., \& Rezaei, S. (2017). Consumer experiences, attitude and behavioral intention toward online food delivey (OFD) services. Journal of Retailing and Consumer Services, 150-162.

\section{Authors' Bibliography}

Kartika Aprilia Benhardy was born in Jakarta on April 21 $1^{\text {st, }}$ 1991. She graduated with a bachelor of economics degree from Universitas Bina Nusantara Jakarta in 2013 and a master of management degree from Universitas Tarumanagara Jakarta in 2018.

Matthew Ronald was born in Jakarta on September $7^{\text {th, }}$ 1996. He graduated with a bachelor of economics degree from Universitas Bina Nusantara Jakarta in 2019. 